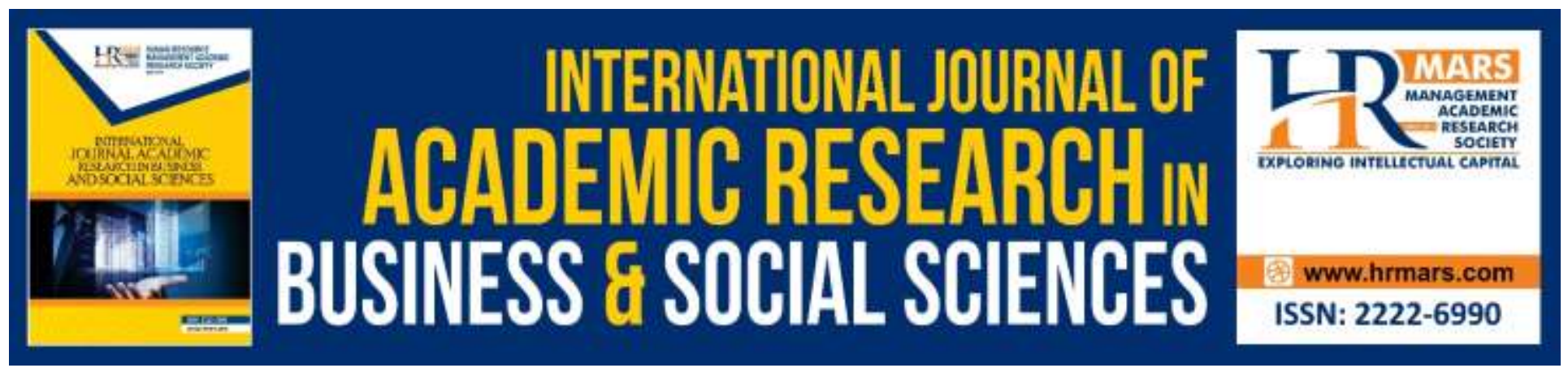

\title{
Conflict Management as a Tool for Increasing Organizational Effectiveness: A Review of Literature
}

John-Eke, Ebere Chika, Akintokunbo, Oluwarotimi Odunayo

To Link this Article: http://dx.doi.org/10.6007/IJARBSS/v10-i5/7198

DOI:10.6007/IJARBSS/v10-i5/7198

Received: 12 March 2020, Revised: 20 April 2020, Accepted: 26 April 2020

Published Online: 14 May 2020

In-Text Citation:(John-Eke \& Akintokunbo, 2020)

To Cite this Article: John-Eke, E. C., \& Akintokunbo, O. O. (2020). Conflict Management as a Tool for Increasing Organizational Effectiveness: A Review of Literature. International Journal of Academic Research in Business and Social Sciences, 10(5), 299-311.

\section{Copyright: (C) 2020The Author(s)}

Published by Human Resource Management Academic Research Society (www.hrmars.com)

This article is published under the Creative Commons Attribution (CC BY 4.0) license. Anyone may reproduce, distribute, translate and create derivative works of this article (for both commercial and non-commercial purposes), subject to full attribution to the original publication and authors. The full terms of this license may be seen

at: http://creativecommons.org/licences/by/4.0/legalcode

\section{Vol. 10, No. 5, 2020, Pg. 299 - 311}

Full Terms \& Conditions of access and use can be found athttp://hrmars.com/index.php/pages/detail/publication-ethics 


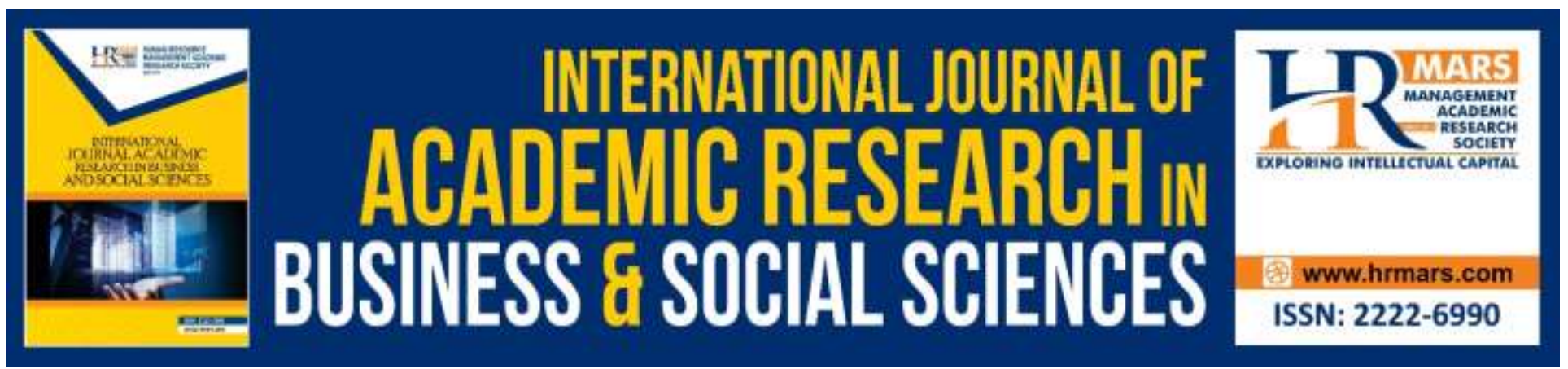

\title{
Conflict Management as a Tool for Increasing Organizational Effectiveness: A Review of Literature
}

\author{
John-Eke, Ebere Chika \\ Doctoral Candidate Department ofManagement, Faculty of Management Sciences, Rivers State \\ University, Nkpolu-Oroworukwo,PMB 5080, Port Harcourt, Nigeria. \\ Email: chikajohneke@gmail.com
}

\author{
Akintokunbo, Oluwarotimi Odunayo PhD \\ Department of Management, Faculty of Management Sciences, Rivers State University, \\ Nkpolu-Oroworukwo, PMB 5080, Port Harcourt, Nigeria \\ Email: Odunayoakintokunbo@yahoo.com
}

\begin{abstract}
The focus of every organization in the society is to create a very conducive environment where employees can carry out their duties effectively without any negative influence that could hinder the achievement of individual and organizational goals. Hence, organizational effectiveness which includes customer/client satisfaction, as well as quality of work-life, is essential to every institution. Nevertheless, conflict in organizations has become unavoidable because employees contend for authority, position, recognition, scarce resources etc. This paper examines conflict management as a tool for increasing organizational effectiveness. The emphasis is on identifying the nature and significance of conflicts in an organization as well as recognizing levels or types of conflict; then asserting the appropriate strategy to be applied to achieve positive outcomes that will lead to organizational effectiveness. Related journals, textbooks and other online publications in Management, Organizational Behaviour, and other relevant fields were reviewed. Our findings revealed that conflicts do not always put the organization in a bad light, but constructively managed conflict brings about healthy competition, strengthens team participation, and bridges the communication gap. We, therefore, recommend that organizations should reeducate their employees on conflict management construct; dispelling the trendy but untrue notion that conflict is bad, destructive and should be avoided at all costs. Managers should adopt strategy or strategies based on the nature and type of conflict.
\end{abstract}

Keywords: Conflict Management, Organizational Effectiveness, Healthy Competition, Scarce Resources, Team Participation. 
INTERNATIONAL JOURNAL OF ACADEMIC RESEARCH IN BUSINESS AND SOCIAL SCIENCES Vol.10,No.5, May, 2020,E-ISSN:2222-6990 @ 2020 HRMARS

\section{Introduction}

Conflict is inevitable among humans be it at home, church or in organization; especially when there is an interaction between two or more individuals, groups or organizations; this is largely caused by differences in individual perception, goal, interest, ideas, feelings, values, etc., that conflict with each other. According to Shetach (2012), Conflict is part of social and business life hence, it is found everywhere. Conflict can be seen as a reality of social life that exists at all levels of society; it can be said to be as old as man. Due to immense social interaction that takes place in an organization, conflict is unavoidable however; its management determines whether the result will be positive or negative. Scholars asserted that many types of relationships such as families, churches, marriages, nations, ethnic groups, and organizations experience conflicts (Deutsch, Coleman \& Marcus 2006; Afful-Broni, 2012).

When conflict is mentioned people tend to perceive it as negative and hardly look at it from a positive angle. We have functional and dysfunctional conflicts; those conflicts that compel us to be creative problem resolvers to maintain a healthy workplace, and come up with a structure that will enable the organization benefit from diversified employees while creating opportunity for redevelopment and acquiring of new skills can be classified as functional conflicts. While those conflicts that negatively affect employees both psychologically and emotionally, that also leads to low productivity can be classified as dysfunctional conflicts. It is imperative to note that how conflicts are managed will determine its outcome either functional or dysfunctional.

While conflict is generally perceived as dysfunctional, it can also be functional; conflict has both positive and negative effects. It can be positive when it enhances creativity, clarification of points of view, and the development of human capabilities to handle interpersonal divergences. There is no anomaly in organizational conflict because it produces or presents an opportunity for modification and settlement between the aggrieved parties for the well being of both the employees and the organization (Osad \& Osas, 2013). Conflict can be negative when it creates resistance to change, establishes uproar, interpersonal relations distrust, low productivity, organizational ineffectiveness (Hotepo, Asokere, Abdul-Azeez, \& Ajemunigbohun, 2010). We will discuss briefly on three types of organizational conflicts, individual, interpersonal and inter-group conflict.

Lamb as cited in Tabitha and Florence (2019), referred to individual conflict as "man against self" conflict, in which such individual state of mind is largely dictated by circumstances within or around him/her. Such as anger, addiction, depression, frustration, confusion, this could result in aggression. It could be a conflict of values, of priorities in which man continues to battle or contend with his mind and habits leading to difficulties in deciding on a goal. Wood et al., as cited in Tabitha and Florence (2019), posits that interpersonal conflict is a conflict that occurs between two or more individuals working together in groups or crew. From the organizational view, this can also be referred to as worker to worker or lateral conflict because it occurs mostly among employees on the same hierarchy; this conflict is part of life and it is present in every organization (Cloke \& Goldsmith, 2011). Nistorescu as cited in Tabitha and Florence (2019), also views this kind of conflict as a means through which an individual or a sector prevents another from achieving the desired goal; he states that if not checkmated early could lead to dangerous situations in future that will affect organizational 
effectiveness. Sometimes conflict could be covert, not all conflict ends in physical exchange of blows or use of weapons.

The next type of conflict is inter-group, this could occur due to differences between two or more groups such as departments or workgroups in an organization, communities, ethnic groups, etc. Pandy was cited in Tabitha and Florence (2019). Other scholars Deutsch and Coleman as cited in Tabitha and Florence (2019), asserts that this kind of conflict may occur from lack of mutual agreement, differences in group goals, limited resource, poor communication channel, overlapping responsibilities, struggle for recognition, etc., hence, management of conflict by managers will determine if it will lead to functional or dysfunctional outcome. Managers in an organization should be able to identify types of conflict that will enable them to apply an appropriate strategy that will create positive results. I align with the view of Ekundayo (2012) that managers should be more concerned with the task of effective conflict management rather than avoiding or detesting it.

Organizational conflict crops up when there is disagreement on how a job or task should be executed; this could be disagreement between individual, inter-personal or intergroup; how this conflict is managed will determine its outcome. According to Riaz and Junaid (2011), ineffective managed organizational conflict leads to reduced confidence levels, stress, and frustration as well as produces anxiety which could cause humiliation, disengagement. It also produces more conflict and destructively affects the entire organization. Effective conflict management enhances organizational development through employee dedication, enthusiasm, absorption it also boosts morale, and stimulates individuals which will in turn lead to organizational effectiveness.

Organizational effectiveness is one of the measures of performance that is used to assess how outputs interact with the economic and social environment. Zheng, Yang and McLean (2010), opined that effectiveness generally determines the policy objectives of the organization or the extent to which organizational goals are realized. Effectiveness is sometimes used to replicate all inclusive performance of an organization because it is broader compared to other concepts of organizational performance. Ability to execute a function with optimal levels of input and output determines the effectiveness of any organization (Amin \& Shila, 2015). Business environment is highly dynamic and ever changing due to globalization, any organization that wants to be relevant and gain competitive advantage must enhance their organizational effectiveness.

\section{Study Objective}

The focus of this paper is to:

- Examine the effect of conflict management styles in organizational effectiveness

- Determine the implication of conflict management on organizational effectiveness

- Find out the best strategy to apply at different levels of conflict management

- Suggest efficient means of conflict management strategy that will enhance organizational effectiveness.

\section{The Concept of Conflict Management}

The focus of every organization in the society is to create a very conducive environment where employees can carry out their duties effectively without any negative influence that could hinder the 
achievement of individual and organizational goals. Nevertheless, conflict in organizations has become unavoidable because employees contend for authority, position, recognition, limited resources etc., No wonder Bercovitch (2011), posits that conflict is inevitable part of living because it is connected to states of scarce resources, division of functions, power relations and roledifferentiation. These contentions most times lead to conflict which sometimes turns out to be either dysfunctional or functional to the organizational effectiveness.

According to Odoh as cited in Nnam (2013), conflict management is a means of curtailing apprehension and the negative influence of conflicts through the application of several measures designed to create awareness as well promote an understanding of the conflict situation by various parties involved. According to Dewa, Corbière, Durand and Hensel (2012), management of conflict is pertinent topic for every business owner, stakeholders etc., because mismanaged conflict can have negative outcomes on organizational effectiveness.

Yusuf-Habeeb and Kazeem (2017) in their study Appraisal of conflict management as a tool for achieving industrial harmony. The focus of this study was to determine ways of sustaining harmonious industrial relations in the future thereby avoiding disruptive conflicts. A total of 300 respondents were used for the study. The findings showed that poor conflict management has devastating effects on industrial organization harmony of Etisalat Nigeria. It also showed that conflict is associated with performance standard targets. Hence, it was recommended that management should improve communication with staff to address issues that can create conflicts before they crop up; that the standards set by management be specific, measurable, realistic, achievable and should have limit; Management should disseminate information or give orders clearly by formally instructing employees on the use of written guidelines such as circular, memo etc., There should be a process to bridge communication gap between management and staff for clear understanding and accurate interpretation of all information which will in turn lead to industrial harmony.

Anku-Tsede and Adjadogo (2016) in their Empirical analysis of workplace conflict and its Influence on the attitude of media employees in Ghana argued that conflict at the workplace have caused destruction or cordial relationships among colleagues as well as subordinates and superiors, affecting employee engagement. Participants comprised 42 respondents from 6 Ghananian print and electronic privately and state owned media houses. Findings proved that attitudes of staff towards work were predominantly influenced negatively as employees decline in commitment to work and cooperation with others. The study also revealed that employees engage in other incivilities such as keeping malice, gossip, hostile behaviours and insecurity. However, the study also discovered some positive aspect of organizational conflict which includes unity, idea sharing, activeness and alertness.

Olukayode (2015) examined the impact of workplace conflict management on organizational performance in a Nigerian manufacturing firm. 250 respondents were selected using the stratified random sampling technique. While data was generated using validated structured questionnaires. Descriptive and inferential statistics were utilized to analyze data collected from the participants. Through the use of Spearman correlation analysis, the results of the empirical tests revealed a significantly positive relationship between conflict management strategies accommodation, collective bargaining and compromise with organizational performance. While non-integrative 
INTERNATIONAL JOURNAL OF ACADEMIC RESEARCH IN BUSINESS AND SOCIAL SCIENCES Vol.10,No.5, May, 2020,E-ISSN:2222-6990 @ 2020 HRMARS

conflict management strategies (domination, competition and avoidance) had a negative statistically determinate effect on organizational performance. Also, the result of the regression analysis showed that collective bargaining strategy demonstrated the highest significant positive correlation with organizational performance. The findings of the study showed that conflicts crop up over several factors of organizational experiences which includes economic and goal incompatibility orientations in the workplace. Management and union conflict of interest was discovered to be the most prevalent form of organizational conflict that exists in the workplace. Therefore, the study concluded that conflict was an inevitable phenomenon in organizational life and can be functional or dysfunctional to organizational effectiveness based on the conflict management strategies employed in the workplace.

Mayowa (2015) Research on Industrial conflict and its management strategies in selected manufacturing companies in Lagos State Nigeria. This study employed co-relational survey method which involves the use of structured questionnaire and personal observation to extract information from the respondents. The respondents were drawn from employees of three manufacturing companies in Lagos, Nigeria. Multistage sampling technique was employed in selecting the respondents from the three manufacturing companies under the study which includes Glaxosmithkline Nigeria, PZ Industries Plc and Nestle Nig Plc. The data collected were analyzed using descriptive statistic including tables, frequency counts, and percentages as well as mean scores. The findings exposed the causes of conflict in manufacturing companies in Lagos State, Nigeria to include poor employee compensation, unfavourable economic and organizational policies, poor means of communicating grievances to echelon managers and poor welfare among others. The study recommended the use of combine strategies such as collaboration, bargaining and avoidance in managing organizational conflict to enhance productive employee to management relationship.

Hotepo, Asokere, Abdul-Azeez and Ajemunigbohun (2010) in their empirical study of the effect of conflict on organizational performance in Nigeria discovered different expectation, lack of cooperation, limited resources, communication problem, competition and interdependence as reasons for conflict in the Nigeria service industry. In another study tagged impact of conflict management on corporate productivity: an evaluative study by Obasan (2011), he acknowledged poor human relations between management and personnel, unacceptable conditions of employment, failure to consult with workers before taking important decisions on issues that concerns them, lack of strategies to prevent conflict and management opposition to union's disposition as major factors to organizational conflict.

Ike (2010) carried out a study in which the Amason and Schwieger (1994) framework was adapted to investigate the impact of conflict on operational decisions and company performance. A Survey was conducted on manufacturing managers in the USA where 392 valid responses were analyzed. From the result it was indicated that when conflict crops up in a manufacturing decision, cognitive conflict would lead to a greater level of company performance especially when the decision situation is based on a market responsive scenario (ground-breaking products). In tandem with past studies, emotional conflict which is common with individual conflict tends to have unfavourable results on effectiveness irrespective of circumstance of the decision. From this study we explicitly understood situations 
INTERNATIONAL JOURNAL OF ACADEMIC RESEARCH IN BUSINESS AND SOCIAL SCIENCES Vol.10,No.5, May, 2020,E-ISSN:2222-6990 @ 2020 HRMARS

where conflict can enhance or hinder organizational effectiveness in operational decision making scenery.

\section{Causes of Conflict in Organization}

There are several contributing factors to conflict in an organization; and scholars have given various views to these factors. Odoh as cited in Nnam (2013), enumerates causative factors of conflict to include no payment or late payment of wages and salaries, management style, condition of employment, social awareness of employees, inappropriate termination of appointment, motivational and promotional factors, awkward dispute and grievances modus operandi, violation of collective agreement, interdependence, management opposition to union disposition, variation in goals and disparity in perception of reality. Similarly, Obasan (2011), acknowledged that causes of conflict in an organization include group members having diverse perception towards one another, bringing different values to their work, insufficient resources, diversity in attitude that leads to different goals, variation in perspective leading to different clarification of the same information, frustration based on inability to achieve set out goals.

Grace (2012) posited that conflict can crop up as a result of operational or personal factors; for proper perspective of organizational conflicts she presented various factors which include personal problems that have to do with relationship issues with partner or family members, this could lead to transferred aggression. Goal differences as a result of goals incompatibility between departments in an organization, interdependence which brings synergy to departments and members working in the organization, personality conflicts because of diversity in individuals, poor communication which creates strife and misunderstanding among management and staff.

Corporate incivility could also lead to conflict in an organization. John-Eke and Gabriel (2019), defined corporate incivility as impolite act meted out to employees by organizations or their agents; the instances include organizations nonchalant responds to sexual harassment report, discriminating practices of the organization; such as religious, sex, marital and ethnic discrimination are so glaring, and insensitivity of the organization to the plight of the employee. These three instances if not properly handled could lead to conflict in the organization. Roles and expectations is another factor that cause conflict in the workplace, this refer to job descriptions which individuals in the organization are expected to execute, nevertheless, conflict can occur among teams especially when individual roles are not clearly stated whereby each employee has a different meaning of the same role (Whitlam \& Cameron, 2012).

\section{Conflict Management Strategy Concept}

The timely identification of nature and significance of sources of conflicts in an organization is the major step in developing conflict management strategies (Elmagri \& Eaton, 2011). The best technique in managing conflicts in an organization is to focus on strategies that will enhance constructive function to optimize organizational effectiveness; therefore, it is important to identify all levels of conflict in organization, be it individual, interpersonal or intergroup conflicts. We should also bear in mind that every organization has its technique of managing conflict with the sole aim of survival. Uchendu, Anijaobi and Odigwe (2013), argued that since conflict is unavoidable in organizations, its management determines whether it will produce positive or negative effect on the organizational 
INTERNATIONAL JOURNAL OF ACADEMIC RESEARCH IN BUSINESS AND SOCIAL SCIENCES Vol.10,No.5, May, 2020,E-ISSN:2222-6990 @ 2020 HRMARS

effectiveness. Proper recognition and immediate clarification of the underlying tension before the conflict ensues or escalates translate to effective management of conflict in an organization.

Some of the early scholars who took interest in conflict and conflict management strategies include Follett (1926-1940), Blake and Mouton (1964), Thomas (1976) etc. Follett as cited in Tabitha and Florence (2019) suggested three main strategies of managing interpersonal conflicts: Domination, compromise and integration; she equally advised that organizations could manage conflicts through avoidance and suppression strategies. Blake and Mouton as cited in Tabitha and Florence (2019), categorizing their strategies based on the level of concern for individuals and production asserts that interpersonal conflicts could be managed through five strategies, forcing, compromising, withdrawing, problem solving and smoothing.

Thomas as cited in Tabitha and Florence (2019) advocated for a two dimensional framework of conflict handling strategies based on assertiveness and cooperativeness of the parties concerned. He acknowledged five conflict management strategies: Competing, compromising, collaborating, accommodating and avoiding. Rahim as cited by Tabitha and Florence (2019), posits that interpersonal conflict could be managed through five strategies, dominating, obliging, integrating, compromising and avoiding based on the level of concerned individuals and those they relate with. All the scholars mentioned in this study agreed on using compromise as one of the strategies for conflict management; though there is huge similarity between Thomas and Rahim strategies, no wonder even in contemporary studies administrators have extensively applied their conflict management strategies (Daly, Lee, Soutar \& Rasmi, 2010).

Some of the important strategies being used for organizational conflicts management are: Collaboration, competition, bargaining, avoidance and compromising. Collaboration strategy is aimed at satisfying the needs of parties concerned especially when the members have mutually significant goals. Competition strategy refers to individual or group desire to meet their goals and objectives either fairly or at the detriment of other groups; in an organization individuals and groups compete for scarce resources, position, recognition, power etc. According to Issa (2009), a very competitive individual's use of power could only be reduced through higher external power such as legitimate law or social taboo when going overboard. Bargaining strategy is used mostly in issues relating to contractual agreement between management and employees for settlement when it becomes a legal matter (Fajana \& Shadare, 2012). It avails all aggrieved parties concerned the chance for equal expression of their mind regardless of the hierarchy of those involved in the dispute without prejudice.

Scholars have diverse views on the use of avoidance strategy in organizational conflict management. Rollag as cited by Abdullah (2015), asserts that not all work groups are teams, because for them to be called a team, all the elements of a team must be embedded in them; these include, commitment, goals, accountability and interdependence. The emphasis is that the conflict management strategy adopted by a group has a way of changing them from group to team. Simmons and Peterson as cited in Abdullah (2015), agreed that avoidance strategy is detrimental to organizational effectiveness because conflicts are unavoidable and never resolved; noting that avoiding conflict could intensify the outcome and also create employees' opposition to management decisions etc. While Abdullah 
INTERNATIONAL JOURNAL OF ACADEMIC RESEARCH IN BUSINESS AND SOCIAL SCIENCES Vol.10,No.5, May, 2020,E-ISSN:2222-6990 @ 2020 HRMARS

(2015) opined that avoidance strategy should be recognized as a viable form of conflict management in some cases; emphasizing that when avoidance strategy is adopted in an organization, it can enhance team building and organizational effectiveness.

Compromising strategy encourages give and take condition which focuses on fulfilling each group's concern (Thomas, Thomas \& Schaubhut, 2008). The parties concerned are willing to settle their differences harmoniously without considering anyone as a winner or beaten. Spaho (2013) opined that compromising entails reaching an agreement amongst individuals or groups concerned in the dispute that has common interest. It is appropriate when parties involved are committed absolutely to mutual actions and also have equal supremacies.

\section{Implication of Conflict Management}

A well managed conflict by the administrators and their teams inspires creativity and fair competition, encourages team participation and diversity of diligence. It creates a healthy working environment that will boost employee satisfaction, increase productivity which will in turn benefit the organizations and their employees.

\section{Concept of Organizational Effectiveness}

Effectiveness is one of the essential concepts in many organizations and this is dependent on collective contributions of management and employees working in such organization; thus, structure of an organization significantly influences its effectiveness because practices of organizational structure are context detailed (Zheng et al.,2010). Robbins (2009) asserts that effectiveness can be equated or compared to the extent to which an organization achieves its goals; he believes that there is no unanimous meaning of effectiveness, pointing that effectiveness is the core subject in organization philosophy and that this concept is very essential to organization. Kohan in Ramesh (2019) opined that organizational effectiveness can be measured in quantity and quality of production and reflects in the superiority of the end product as associated with a series of organizational goals. Workforce diversity could also influence organizational effectiveness; because diversity leads to synergy among the different skills and competences inherent in the organization, this tends to encourage collaborative work situation, drive productivity and lead to excellent business performance (Tamunomiebi \& John-Eke, 2020). Effectiveness is pertinent at all levels of organization because it gives them competitive advantage over their opponents; no wonder Drucker considered effectiveness as key to managerial success.

Noruzi and Rahimi (2010), states that the fundamental objective of most research on organizations is to enhance their effectiveness. Organizational effectiveness is a wider phrase encompassing various components used in evaluating organizational performance. Hence, it has been liken to an aspect of organizational performance. Early scholars such as (Mott, 1972; Steers, 1977), have given various definitions of organizational effectiveness yet some still believe that it has been difficult to accurately define this phenomenon (Rahimi \& Noruzi, 2011). Organizational theory has articulated diverse models for organizational effectiveness ranging from participant satisfaction, rational goal, internal process and system resource while measures developed by Mott (1972) productivity; adaptability and efficiency are mostly used even by contemporary scholars. 
INTERNATIONAL JOURNAL OF ACADEMIC RESEARCH IN BUSINESS AND SOCIAL SCIENCES Vol.10,No.5, May, 2020,E-ISSN:2222-6990 @ 2020 HRMARS

There is emergent concern about attaining excellent service delivery to clients by organizations. Due to globalization and advancement in technology, some organizations can set up modern technology processes to accomplish growth. Organizations that have skilled, excellent, experienced and dedicated manpower are probable to survive. Hence organizations should invest in human capital development to empower the employees (Kondalkar, 2009). From the various reviews of effectiveness, it is the measure or extent to which an organization achieves its goals or mission; hence, constructive conflict management in an organization will enhance employee commitment making them more engaged to their responsibilities thereby improving organizational effectiveness.

\section{Conclusion}

Conflict is part of daily social life that is inevitable; therefore it is imperative that the manager identifies the nature and significance of conflicts in an organization as well as recognizing levels or types of conflict. This paper examined conflict management as a tool for increasing organizational effectiveness. Conflict has been viewed as evil, but constructive conflict management is a high point for any organization. Hence, conflict management is the means of reducing the dysfunctional aspect of this phenomenon while increasing the functional aspect of it. The purpose of conflict management in an organization is to create a very good conducive workplace atmosphere free of resentment, incivility, violence etc., which could lead to physical, psychological or financial damages to both employees and the organization.

The mission of most organizations is focused on client/customer satisfaction through effective service delivery, to this end effectual conflict management becomes an essential duty of a manager to encourage employee engagement and to maintain Competitive advantage. Conflict is frequently seen as dysfunctional but from reviewed literature, it has been established that it is not every conflict that results in negative effects on organizations but some have positive effects on team participation. Therefore, when conflict is properly managed, it enhances learning, creates the spirit of teamwork and cooperation; which is capable of increasing organizational innovation due to diversity of workforce, thereby leading to effectiveness or performance in an organizational setting.

\section{Implications}

Theoretical and Contextual

The results of this study provide both theoretical and contextual implications. This study represents the theoretical or library research regarding the application of Conflict Management strategies as tool for increasing organizational effectiveness. Despite the fact that Conflict Management is an integral tool for increasing organizational effectiveness, there have been few empirical researches on Conflict Management as a veritable tool for increasing organizational effectiveness. As expected, this study revealed the importance and impact of interpersonal working relationships in understanding employees' perceptions of fairness. This galvanized our understanding of the Conflict Management factors fundamental to increasing organizational effectiveness. Thus, this study provides a basis for research in Conflict Management as a tool for increasing organizational effectiveness. Second, since this research was conducted as a library research, it will be a pool of valuable resources to other researchers whose studies will be conducted within the context of the organization. Since the validity of the results of this "laboratory experiment" may be questioned, the results from empirical studies will provide evidence of validity in the work setting. 
INTERNATIONAL JOURNAL OF ACADEMIC RESEARCH IN BUSINESS AND SOCIAL SCIENCES Vol.10,No.5, May, 2020,E-ISSN:2222-6990 @ 2020 HRMARS

\section{Recommendations}

Several strategies can be used in managing organizational conflict; from extant literature reviewed, we recommend that organizations should re-educate their employees on conflict management constructs; dispelling the trendy but untrue notion that conflict is always bad, destructive and should be avoided at all cost. Managers should adopt strategy or strategies based on the nature and type of conflict. They should also bear in mind that irrespective of the challenges conflict may pose on organization, the focus should always be on proper management that will lead to functional outcome, conflict management is a laudable predictor of organizational effectiveness therefore, every company should focus on constructive conflict management which will bring about employee engagement that will in turn influence organizational effectiveness.

\section{References}

Abdullah, A. S. A. (2015). The Impact of Conflict Management on Organizational Effectiveness: A Case Study of Ministry of Higher Education of Jordan. European Journal of Business and Management, 7 (36), 75-79.

Afful-Broni, A. (2012). Conflict management in Ghanaian schools: a case study of the role of leadership of Winneba Senior High School. Journal of Educational Planning \& Administration, 2(2), 65-76.

Amin, T., \& Shila, S. (2015). Enhancing organizational effectiveness by performance appraisal, training, employee participation, and job definition. European Journal of Business and Management,7(12),56-63.

Anku-Tsede, O., \& Adjadogo, N. (2016). Empirical analysis of workplace conflict and its influence on the attitude of media employees in Ghana. Journal of Management Policy and Practice. 17(1), 106-117.

Bercovitch, J. (2011). Conflict and conflict management in Organisations: A Framework for analysis. Retrieved : http://www.aspheramedia.com/v2/ 20/03/2020.

Cloke, K., \& Goldsmith, J. (2011). Resolving conflicts at work: Ten strategies for everyone on the job(3rd ed.). San Francisco: Jossey-Bass, United States of America.

Daly, T. M., Lee, J. A., Soutar, G. N., \& Rasmi, S. (2010). 'Conflict-handling style measurement: a bestworst scaling application'. International Journal of Conflict Management, 21(3), 281-308.

Deutsch, M., Coleman, P. T., \& Marcus, E. C. (2006). The handbook of conflict resolution: theory and practice $2^{\text {nd }}$ edition, Jossey- Bass, United States of America.

Dewa, C. S., Corbière, M., Durand, M. J., \& Hensel, J. (2012). Challenges related to mental health in the workplace. In R. J. Gatchel \& I. Z. Schultz (Eds.), Handbook of occupational health and wellness. 105-129.

Ekundayo, H. T. (2012). Towards strengthening the relationship between trade unions and university management in Nigeria. An International Multidisciplinary Journal, Ethiopia, 6(2), 266-273.

Elmagri, M. I., \& Eaton, D. (2011). Identifying the factors causing interpersonal conflict in organizations: Through analysing secondary data. The Built \& Human Environment Review, $4(1), 6$.

Fajana, S., \& Shadare, O. (2012). Workplace relations, social dialogue and political milieu in Nigeria. International Journal of Business Administration, 3(1), 75-83. 
INTERNATIONAL JOURNAL OF ACADEMIC RESEARCH IN BUSINESS AND SOCIAL SCIENCES Vol.10,No.5, May, 2020,E-ISSN:2222-6990 @ 2020 HRMARS

Grace, N. (2012). What causes conflict between employees in an organization? Retrieved from http://smallbusiness.chron.com/causes-conflict-betweenemployees-organization-157.html. 05/04/2020

Hotepo, O. M., Asokere, A. S. S., Abdul-Azeez, I. A., \& Ajemunigbohun, S. S. A. (2010). Empirical Study of the Effect of Conflict on Organizational Performance in Nigeria. Business and Economics Journal, 15 (1), 2151-6219.

Ike, C. E. (2010). The impact of conflict on manufacturing decisions and company performance. International Journal of Production Economics, 126(2), 145-157.

Issa, I. A. F. Z. (2009). Organizational conflict management strategies and their relationship to business ethics management, for heads of departments in the faculties of nursing in the Jordanian private universities from the perspective of faculty members, the Middle East University for Graduate Studies. Faculty of Educational Sciences. Retrieved from www.meu.edu.jo 05/04/2020.

John-Eke, E. C., \& Gabriel, J. M. O. (2019). Corporate incivility and employee engagement. West African Journal of Business, 13(1), 1595-3750.

Kondalkar, V. G. (2009). Organization Effectiveness and Change Management. PHL Learning Private Limited, New Delhi- 110001.

Mayowa, S. O. (2015). "Industrial conflict and its management in selected Nigerian manufacturing companies". International Journal of Organizational Leadership. 4, 430-439.

Nnam, M. U. (2013). Conflict and conflict management: A springboard for success and progress in organisations in Nigeria. International Journal of Development and Management Review, 8(1), 63-73.

Noruzi, M. R., \& Rahimi, G. R. (2010). Multiple intelligences: A New look to organizational effectiveness. Journal of Management Research. 2(2).

Obasan, K. (2011). Impact of conflict management on corporate productivity: An Evaluative study. Australian Journal of Business and Management Research, 1(5), 44-49.

Olukayode, L. (2015). Impact of workplace conflict management on organizational performance: A Case of Nigerian manufacturing firm. Journal of Management and Strategy, 6(2), 83-92.

Osad, O. I.,\& Osas, U. E. (2013). Harmonious industrial relations as a panacea for ailing enterprises in Nigeria. Journal of Asian Scientific Research, 3(3), 229-246.

Rahimi, G. R., \& Noruzi, M. R. (2011). Can intelligence improve organizational effectiveness? Interdisciplinary Journal of Contemporary Research in Business, 2 (10).

Ramesh, D. M. (2019). Employee empowerment and organizational effectiveness in the organizations. International Journal of Scientific Research in Management and Business Administration, 1(1), 5-11.

Riaz, M. K., \& Junaid, F. A. (2011). Types, sources, costs and consequences of workplace conflict. Asian Journal of Management Research, 2(1), 600-611.

Robbins, S. P. (2009). Organizational theory: Structure, design and application. Translated by Seyed Mehdi Alvani and Hasan Danaei Fard, Safar Publication, 29th edition, Tehran.

Shetach, A. (2012). Dilemmas of ethics committees' effectiveness: A management and team theory contribution. Clinical Ethics, 7(2), 94-100.

Spaho, K. (2013).Organizational Communication and Conflict Management. Management, 18(1), 103-118. 
INTERNATIONAL JOURNAL OF ACADEMIC RESEARCH IN BUSINESS AND SOCIAL SCIENCES

Vol.10,No.5, May, 2020,E-ISSN:2222-6990 @ 2020 HRMARS

Tabitha, M., \& Florence, G. (2019). Conflicts and conflict management in modern organizations-A pre-conflict resolution environment approach. International Journal of Scientific and Research Publications, 9(8), 2250-3153.

Tamunomiebi, M. D., \& John-Eke, E. C. (2020). Workplace Diversity: Emerging Issues in Contemporary Reviews. International Journal of Academic Research in Business and Social Sciences, 10(2), 255-265.

Thomas, K. W., Thomas, G. F., \& Schaubhut, N. (2008). Conflict styles of men and women at six organization levels. International Journal of Conflict Management, 19(2), 148-166.

Uchendu, C., Anijaobi, F., \& Odigwe, F. (2013). Conflict management and organizational performance in secondary schools in Cross Rivers State. Nigeria Research Journal in Organizational Psychology and Educational Studies, 2(2), 67-71.

Whitlam, D. A., \& Cameron, K. S. (2012). Developing Management Skills, 7th edition, Prentice Hall, New Jersey. Pears Education, Inc.

Yusuf-Habeeb, M. O., \& Kazeem, A. O. (2017). Appraisal of conflict management as a tool for achieving industrial harmony. Nile Journal of Business and Economics, (7), 28-51.

Zheng W., Yang B., \& McLean G. (2010). Linking organizational culture, structure, strategy, and organizational effectiveness: Mediating role of knowledge management. Journal of Business Research, 63(7),763-771. 